The cause of the hypercoagulable phase in Case 4, which developed on the third day and has continued, is uncertain. It may be related to the formation of fibrin clots during the rejection phase, though on histological examination the small hepatic arterial vessels in the portal tracts were patent. It is of interest that during the period of rejection there was a significant decrease in platelet count. Mowbray (1968) has shown that during rejection of the kidney in man platelet thrombi form in the arterioles and capillaries, and that immediately preceding an episode of clinical rejection there is a fall in the blood platelet count. Starzl et al. (1968a, 1968b) observed marked thrombocytopenia in three cases with a prolonged survival, which developed during the second and third weeks, with a rise to normal or near-normal levels during the ensuing one to three months. The cause of the leucocytosis between days 7 and 14 in our patients is uncertain. This has been observed at a similar time in patients with renal transplants.

The ultimate cause of death in Case 3 was overwhelming bacterial and fungal infection. The extensive hepatic necrosis found at necropsy was almost certainly ischaemic in origin, resulting from the thrombosis of the hepatic artery. The thrombus, which involved only the recipient part of the hepatic artery, was probably due to injury to the endothelium from the application of a clamp during the transplantation operation. This was probably at the root of many of the complications which later developed, including gangrene of the donated gall bladder, the biliary fistula, and hepatic ischaemia. This, together with the diminished resistance with the immunosuppression, was the basis for the recurrent and finally massive infection.

Infections have also been a major problem in the cases done by Starzl and his group (Fulginiti et al., 1968). Of the eight patients treated before July 1967 all died with a variety of infections within 34 days. Gram-negative bacilli, Candida albicans, and cytomegalovirus were all implicated. Of nine cases operated on between then and May 1968, five were also troubled by infections. In each case these were superimposed on a syndrome of hepatic lobar gangrene and hepatic arterial thrombosis, which was attributed to inadequate fixation of the liver to the diaphragm. In the four most recent patients, who had survived for periods of up to five and a half months at the time of the report and in whom the liver had been fixed to the diaphragm, there had been only minor episodes of sepsis.
Patients having hepatic transplantation must be carefully screened for infection, and daily skin and throat swabs and cultures of urine, faeces, and blood are essential. Cytomegalovirus is particularly important, because it may cause a hepatitis with cholestatic features (Toghill et al., 1967). Serum should be examined for a rise in complement-fixing antibodies, and examination of the urine should be done at regular intervals. The virus may not be excreted until four to six weeks after the initial infection of the liver. Whether a patient should have prophylactic antibiotics before operation and whether the gastrointestinal tract should also be sterilized are debatable. It does not prevent superimposed infections in other circumstances and may indeed contribute to the emergence of resistant strains. Prompt treatment of the specific infection by the appropriate antibiotic is to be preferred.

The prolonged survival of the two patients reported herein particular, the return to work of Case 4 and his excellent general health and liver function at present-provide us with considerable hope that orthotopic transplantation of the liver will have much to offer in the treatment of patients with primary hepatic malignancy or advanced cirrhosis.

We have already expressed our indebtedness to the many colleagues and the departments concerned in these transplantations.

The antilymphocyte globulin in the first case was kindly provided by Professor M. F. A. Woodruff, of Edinburgh, and that used in the second case by Professor W. Brendel, of Munich. We also thank Mrs. Angela Birbeck for the drawings.

\section{REFERENCES}

Alkjaersig, N., Fletcher, A. P., and Sherry, S. (1959). F. clin. Invest., 38, 1086.

Calne, R. Y., and Williams, R. (1968). Brit. med. F., 4,

Calne, R. Y., and Wiliams, R. (1968). Brit. med.

Flanc, C., Kakkar, V. V., and Clarke, M. B. (1968). Brit. ₹. Surg., 55, 742 .

Flute, P. T. (1964). Brit. med. Bull., 20, 195.

Fulginiti, V. A., et al. (1968). New Engl. ł. Med., 279, 619.

Hardisty, R. M., and Ingram, G. I. C. (1965). Bleeding Disorders, p. 255. Oxford.

Merskey, C., Kleiner, G. J., and Johnson, A. J. (1966). Blood, 28, 1. Mistilis, S. P., and Blackburn, C. R. B. (1967). Aust. Ann. Med., 16, 305

Moore, F. D. (1967). In The Liver, edited by A. E. Read. London.

Mowbray, J. F. (1968). Proc. roy. Soc. Med. In press.

Mowbray, J. F. (1968). Proc. roy. Soc. Med. In press. (1967). Lancet, 1, 1351.

Starzl, T. E., et al. (1968a). Surgery, 63, 549.

Starzl, T. E., et al. (1968b). Ann. Surg., 168, 392.

\title{
Absorption and Utilization of Polyglutamyl Forms of Folate in Man
}

\author{
JANET PERRY,* B.SC. ; I. CHANARIN, $\dagger$ M.D., D.C.P., M.C.PATH.
}

$S^{\text {un }}$ mary : Some three-quarters of folate compounds in mixed diet have a chain of seven glutamic acid residues (polyglutamates). The extent to which these forms of folate are absorbed and utilized by man is of considerable nutritional importance. These studies indicate that the polyglutamate forms were absorbed and utilized to about one-third of the extent of simpler (monoglutamate) forms, as judged by the serum folate levels after oral equimolar doses, by the amount incorporated into red cells in long-term studies, by the amount excreted into the urine, and by their capacity to initiate haematological responses in patients with folate-deficient megalological responses
blastic anaemias.

\footnotetext{
* Technical Officer, M.R.C. Experimental Haematology Research Unit, + Reader in Haematology, St. Mary's Hospital Medical School, London W.2.
}

\section{Introduction}

Folate compounds may be divided into two groups, the one having a single glutamic acid residue such as pteroylglutamic acid (PteGlu) and the other a chain of seven glutamic acid residues-that is, pteroylheptaglutamate $\left(\mathrm{PteGlu}_{7}\right)$ (Binkley et al., 1944 ; Pfiffner, Calkins, Bloom, and O'Dell, 1946). The simpler forms, with the addition of a form having three glutamic acid residues (pteroyltriglutamate), are able to support the growth of microbiological assay organisms such as Lactobacillus casei, and these forms have been collectively termed "free" folates. These forms are readily absorbed from the gut (Anderson, Belcher, Chanarin, and Mollin, 1960), and they constitute some $25 \%$ of the folates in a normal cooked diet (Butterworth, Santini, and Frommeyer, 1963; Chanarin, Rothman, Perry, and Stratfull, 1968). The remaining $75 \%$ of dietary folate is not detected by microbiological assay until the 
glutamic acid chain has been removed by the action of a "conjugase" enzyme most conveniently obtained from chick pancreas. The extent to which this form of folate $\left(\mathrm{PteGlu}_{7}\right)$ is absorbed and the manner in which it is absorbed and utilized by man are not known at the present time. The purpose of this study was to obtain information on these aspects of folate metabolism.

\section{Materials and Methods}

Preparation of Heptaglutamate.-Yeast is a rich source of folate containing almost all the folate in the heptaglutamate forms. Brewer's yeast was kindly donated by the Guinness brewery, and $500 \mathrm{~g}$. was made up to 2 litres in $1 \%$ aqueous ascorbate. This was heated for five minutes at $15 \mathrm{lb}$. pressure and the $\mathrm{pH}$ adjusted to 4 with glacial acetic acid. The folate was absorbed on to $250 \mathrm{~g}$. of charcoal partially deactivated by the addition of stearic acid (Asatoor and Dalgliesh, 1956) and allowed to stand, with occasional stirring, for one hour. The charcoal was filtered through a Buchner funnel, washed with a litre of distilled water, and folate was eluted by washing with 2 litres of ammoniacal ethanol. The eluate was evaporated to dryness in a rotary evaporator and the dried residue stored in the dark. This procedure resulted in recovery of 50 to $60 \%$ and fifteenfold concentration of folate. An average of $97 \%$ was in the form of PteGlu and some $3 \%$ as free folate.

Preparation of Chick Pancreatic Extract.-Commercially available dried chick pancreas proved unsatisfactory. Fresh chick pancreas from 10 animals was obtained and transported to the laboratory in the frozen state. It was cut into small pieces and ground in a mortar in the presence of 5 volumes of acetone. This was repeated with a further aliquot of acetone, the pancreatic extract being dried at room temperature and stored at $4^{\circ} \mathrm{C}$. Further removal of folates and other interfering substances was carried out as described by Iwai, Luttner, and Toennies (1964) by absorption with Amberlite IR 400 for one hour.

Preparation of Samples for Assay.-Samples of heptaglutamate in aqueous suspension $(0.1 \mathrm{ml}$.) were incubated with $0.1 \mathrm{ml}$. of conjugase suspension in $10 \mathrm{ml}$. of $0.1 \mathrm{M}$ phosphate buffer $p H \quad 7.2$ containing $600 \mathrm{mg}$. of ascorbate $/ 100 \mathrm{ml}$. for five hours at $37^{\circ} \mathrm{C}$. Controls of the specimen without conjugase and of conjugase alone were treated in the same way. After incubation the samples were brought to $\mathrm{pH} 5.7$ with $\mathrm{HCl}$, heated for 10 minutes at $10 \mathrm{lb}$. pressure, filtered, and the clear filtrate retained for assay. The folate value of the specimen containing chick pancreatic extract alone was subtracted from the value of specimen of heptaglutamate plus enzyme. The mean recovery of yeast heptaglutamate added to serum and assayed in this manner was $99 \%$ of the expected value, with a range from 78 to $121 \%$ in 18 assays.

Preparations of Felate.-Solutions of folate for absorption tests were prepared from dried synthetic pteroylglutamic acid dissolved in $0.2 \mathrm{~N} \mathrm{NaOH}$ at a concentration of $2 \mathrm{mg} . / \mathrm{ml}$. Folate tablets containing $100 \mu \mathrm{g}$. of pteroylglutamic acid were prepared by the hospital pharmacy. Yeast tablets containing $300 \mathrm{mg}$. of dried yeast, so that 17 tablets supplied the equivalent of $100 \mu \mathrm{g}$. of PteGlu as heptaglutamate and $3.2 \mu \mathrm{g}$. of PteGlu, were used as a source of heptaglutamate in long-term studies and in haematological response studies.

Microbiological Assay Methods.-Assays of serum, red cell folate, and the various folate preparations were carried out by the methods described by the U.S. Association of Official Agricultural Chemists, dehydrated media being used. One gramme of ascorbate was added to every $500 \mathrm{ml}$. of medium used in the $L$. case $i$ assay. Red cells were prepared for assay by the method of Hoffbrand, Newcombe, and Mollin (1966). Sera for assay were deproteinized in $0.1 \mathrm{M}$ phosphate ascorbate buffer at $p \mathrm{H} 5.7$ with a 1 in 50 dilution of serum. Organisms used were $L$. casei and Streptococcus faecalis.
Plan of Study

The purpose of the study was to compare in man the manner in which equimolar amounts of PteGlu and PteGlu (1) were $^{2}$ absorbed, measuring serum folate levels after $0.045 \mu \mathrm{M}$ per $\mathrm{kg}$. oral doses of each equivalent to $20 \mu \mathrm{g}$. of PteGlu per $\mathrm{kg}$.; (2) were excreted into the urine after these same doses; (3) were utilized, by noting the effects on red cell folate levels in longterm studies; and (4) induced haematological responses when given sequentially to folate-deficient patients with megaloblastic anaemia.

\section{Intestinal Absorption of PteGlu and PteGlu,}

Absorption studies with both compounds were carried out on five healthy members of the laboratory staff. The subjects were not saturated with folate before the study and a few days elapsed between each test. Following collection of a fasting blood sample an oral dose of $0.045 \mu \mathrm{M}$ of folate per $\mathrm{kg}$. was given and blood samples were collected at hourly intervals. The sera were assayed with Str. faecalis and L. casei both before and after enzyme treatment. The results (see Tables I and II and Fig. 1) show that much higher serum folate values were obtained with PteGlu than with PteGlu all subjects with PteGlu was evident in the first hourly specimen, whereas it was reached only in the third hour with PteGlu,

TABLE I.-Serum Folate Levels After $0.045 \mu \mathrm{M}$ Folate per kg. Orally Either as Preroylglutamic

\begin{tabular}{|c|c|c|c|c|c|c|c|c|c|}
\hline \multirow{2}{*}{$\begin{array}{l}\text { Sub- } \\
\text { ject }\end{array}$} & \multicolumn{2}{|c|}{$\begin{array}{l}\text { Oral Dose } \\
(\mu \mathrm{g} .)\end{array}$} & \multirow{2}{*}{ Assay } & \multirow{2}{*}{$\begin{array}{c}\text { 'Conju- } \\
\text { gase' } \\
\text { Enzyme }\end{array}$} & \multicolumn{4}{|c|}{$\begin{array}{l}\text { Serum Folate } \\
(\mathrm{m} \mu \mathrm{g} . / \mathrm{ml} .)\end{array}$} & \multirow{2}{*}{$\begin{array}{l}\text { Urine } \\
(\mu \mathrm{g} .)\end{array}$} \\
\hline & PteGlu & PteGlu $_{7}$ & & & 0 & $1 \mathrm{hr}$ & $2 \mathrm{hr}$ & $3 \mathrm{hr}$ & \\
\hline 1 & 1,160 & 1,140 & $\left.\begin{array}{c}\text { Str. } \\
\text { faec. } \\
\text { L. } \\
\text { casei } \\
\text { Str. } \\
\text { faec. } \\
\text { L. } \\
\text { casei }\end{array}\right\}$ & $\begin{array}{l}\text { No } \\
\text { Yes } \\
\text { No } \\
\text { Yes } \\
\text { No } \\
\text { Yes } \\
\text { No } \\
\text { Yes }\end{array}$ & $\begin{array}{l}0 \\
0 \\
4 \\
6 \\
0 \\
0 \\
3 \\
5\end{array}$ & $\begin{array}{r}20 \\
30 \\
38 \\
36 \\
4 \\
7 \\
6 \\
10\end{array}$ & $\begin{array}{r}30 \\
30 \\
36 \\
33 \\
8 \\
14 \\
17 \\
16\end{array}$ & $\begin{array}{l}16 \\
18 \\
29 \\
35 \\
16 \\
14 \\
21 \\
25\end{array}$ & $\begin{array}{c}40 \\
65 \\
157 \\
0.49 \\
0.77 \\
2.6 \\
2.9\end{array}$ \\
\hline 2 & 1,450 & 1,400 & $\begin{array}{c}\text { Str. } \\
\text { faec. } \\
\text { L. } \\
\text { casci } \\
\text { Str. } \\
\text { faec. } \\
\text { L. } \\
\text { casei }\end{array}$ & $\begin{array}{l}\text { No } \\
\text { Yes } \\
\text { No } \\
\text { Yes } \\
\text { No } \\
\text { Yes } \\
\text { No } \\
\text { Yes }\end{array}$ & $\begin{array}{l}0 \\
0 \\
3 \\
9 \\
0 \\
0 \\
5 \\
8\end{array}$ & $\begin{array}{l}32 \\
32 \\
41 \\
33 \\
13 \\
12 \\
10 \\
13\end{array}$ & $\begin{array}{r}18 \\
18 \\
23 \\
24 \\
8 \\
8 \\
18 \\
16\end{array}$ & $\begin{array}{r}13 \\
4 \\
20 \\
15 \\
8 \\
3 \\
14 \\
12\end{array}$ & $\begin{array}{l}46 \\
46 \\
75 \\
75 \\
0.4 \\
0.45 \\
5.5 \\
6.5\end{array}$ \\
\hline 3 & 1,260 & 1,220 & $\begin{array}{l}\text { Str. } \\
\text { faec. } \\
\text { L. } \\
\text { casei } \\
\text { Str. } \\
\text { faec. } \\
\text { L. } \\
\text { casei }\end{array}$ & $\begin{array}{l}\text { No } \\
\text { Yes } \\
\text { No } \\
\text { Yes } \\
\text { No } \\
\text { Yes } \\
\text { No } \\
\text { Yes }\end{array}$ & $\begin{array}{l}0 \\
0 \\
3 \\
4 \\
0 \\
0 \\
3 \\
4\end{array}$ & $\begin{array}{r}30 \\
48 \\
-50 \\
48 \\
0 \\
2 \\
4 \\
7\end{array}$ & $\begin{array}{r}26 \\
26 \\
27 \\
38 \\
0 \\
0 \\
4 \\
7\end{array}$ & $\begin{array}{r}18 \\
30 \\
22 \\
16 \\
0 \\
0 \\
6 \\
7\end{array}$ & $\begin{array}{l}127 \\
150 \\
180 \\
240 \\
1.3 \\
1.3 \\
3.9 \\
3.9\end{array}$ \\
\hline 4 & 1,550 & 1,520 & $\left.\begin{array}{c}\text { Str. } \\
\text { faec. } \\
\text { L. } \\
\text { casei } \\
\text { Str. } \\
\text { faec. } \\
\text { L. } \\
\text { casei }\end{array}\right\}$ & $\begin{array}{l}\text { No } \\
\text { Yes } \\
\text { No } \\
\text { Yes } \\
\text { No } \\
\text { Yes } \\
\text { No } \\
\text { Yes }\end{array}$ & $\begin{array}{r}0 \\
0 \\
8 \\
16 \\
0 \\
0 \\
11 \\
11\end{array}$ & $\begin{array}{l}47 \\
43 \\
53 \\
61 \\
10 \\
12 \\
11 \\
9\end{array}$ & $\begin{array}{r}23 \\
32 \\
46 \\
41 \\
6 \\
7 \\
10 \\
16\end{array}$ & $\begin{array}{r}5 \\
10 \\
16 \\
19 \\
10 \\
10 \\
11 \\
9\end{array}$ & $\begin{array}{l}350 \\
350 \\
420 \\
448 \\
1.5 \\
1.5 \\
6.8 \\
9.5\end{array}$ \\
\hline 5 & 1,480 & 1,440 & $\begin{array}{c}\text { Str. } \\
\text { faec. } \\
\text { L. } \\
\text { casei } \\
\text { Str. } \\
\text { faec. } \\
\text { L. } \\
\text { casei }\end{array}$ & $\begin{array}{l}\text { No } \\
\text { Yes } \\
\text { No } \\
\text { Yes } \\
\text { No } \\
\text { Yes } \\
\text { No } \\
\text { Yes }\end{array}$ & $\begin{array}{r}0 \\
0 \\
3 \\
17 \\
0 \\
0 \\
5 \\
2\end{array}$ & $\begin{array}{r}26 \\
36 \\
38 \\
33 \\
0 \\
3 \\
5 \\
4\end{array}$ & $\begin{array}{r}20 \\
26 \\
29 \\
24 \\
0 \\
10 \\
5 \\
6\end{array}$ & $\begin{array}{r}20 \\
30 \\
27 \\
22 \\
0 \\
8 \\
7 \\
9\end{array}$ & $\begin{array}{l}230 \\
230 \\
232 \\
300 \\
1 \cdot 1 \\
2 \cdot 4 \\
2 \cdot 2 \\
3 \cdot 7\end{array}$ \\
\hline
\end{tabular}

A substantial amount of folate in plasma following oral heptaglutamate appeared directly available to the assay organisms, and hence was probably absorbed after deconjugation. Some was probably absorbed as PteGlu, since there were slightly higher levels throughout after enzyme treatment of the serum samples, though these differences were not statistically significant.

At one hour after PteGlu, higher values were obtained with Str. faecalis than with $L$. casei, suggesting the possibility that some pteroic acid (Pte) was present in this sample, though again the differences did not reach statistical significance. 
TABLB II.-Mean Folate Absorption After Equimolar Oral Doses of Monoglutamate and Heptaglutamate Forms of Folate $(0.045 \mu \mathrm{M} / \mathrm{kg}$.)

\begin{tabular}{|c|c|c|c|c|c|c|c|}
\hline & \multirow{2}{*}{ Organism } & \multirow{2}{*}{$\begin{array}{c}\text { Conju- } \\
\text { gase }\end{array}$} & 0 & $1 \mathrm{hr}$ & $2 \mathrm{hr}$ & $3 \mathrm{hr}$ & \multirow{2}{*}{$\begin{array}{l}\text { Urine } \\
(\mu \mathrm{g} .)\end{array}$} \\
\hline & & & \multicolumn{4}{|c|}{$(\mathrm{m} \mu \mathrm{g} . / \mathrm{ml})}$. & \\
\hline PteGlu & $\begin{array}{l}\text { Str. faec. } \\
\text { *L. casei }\end{array}$ & $\begin{array}{l}\text { No } \\
\text { Yes } \\
\text { No } \\
\text { Yes }\end{array}$ & $\begin{array}{l}0 \\
0 \\
0 \\
6\end{array}$ & $\begin{array}{l}31 \\
38 \\
40 \\
38\end{array}$ & $\begin{array}{l}23 \\
26 \\
28 \\
28\end{array}$ & $\begin{array}{l}14 \\
19 \\
19 \\
14\end{array}$ & $\begin{array}{l}159 \\
168 \\
213 \\
266\end{array}$ \\
\hline PteGlu $_{7}$ & $\begin{array}{l}\text { Str. faec. } \\
\text { *L. casei }\end{array}$ & $\begin{array}{l}\text { No } \\
\text { Yes } \\
\text { No } \\
\text { Yes }\end{array}$ & $\begin{array}{l}0 \\
0 \\
0 \\
1 \cdot 2\end{array}$ & $\begin{array}{l}5 \cdot 4 \\
7 \cdot 4 \\
1 \cdot 8 \\
3 \cdot 8\end{array}$ & $\begin{array}{l}4 \cdot 4 \\
7 \cdot 8 \\
5 \cdot 6 \\
6 \cdot 8\end{array}$ & $\begin{array}{l}6.8 \\
7.0 \\
6 \cdot 4 \\
8.0\end{array}$ & $\begin{array}{l}0.97 \\
1 \cdot 28 \\
4 \cdot 2 \\
5 \cdot 3\end{array}$ \\
\hline
\end{tabular}

* The $L$. casei serum folate value in the fasting specimen has been subtracted from all the values.

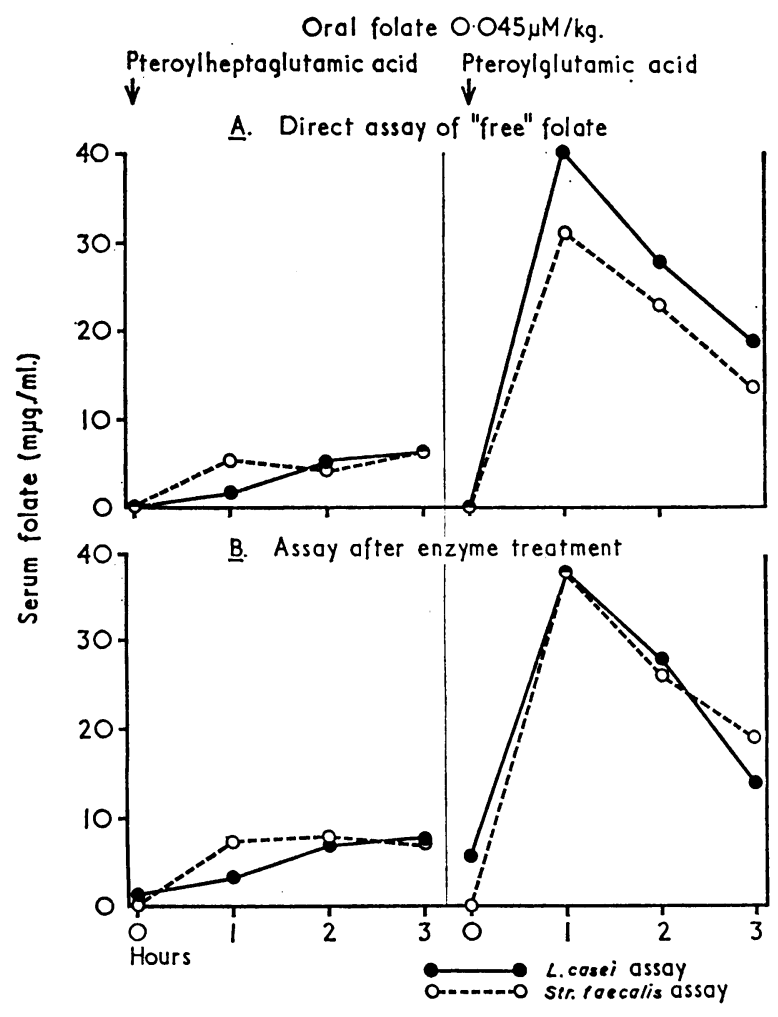

Fig. 1.-Serum folate levels after $0.045 \mu \mathrm{M}$ folate per $\mathrm{kg}$. as monoglutamate and heptaglutamate.

With PteGlu, higher values were obtained with $L$. casei than with Str. faecalis before enzyme treatment, suggesting that $L$. casei was also responding to displaced tissue folates not available to Str. faecalis (Chanarin and McLean, 1967). These differences disappeared after enzyme treatment.

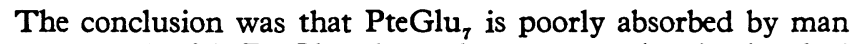
as compared with PteGlu, that a large proportion is absorbed after removal of the peptide chain, but that some may be absorbed unchanged, particularly in certain subjects (Subject 5). Absorption studies in two patients with idiopathic steatorrhoea appeared to show a more severe impairment of absorption with PteGlu than with PteGlu,

The results obtained are not likely to have been influenced by the small amount of free folate in the $\mathrm{PteGlu}_{7}$ preparations, since doses of this magnitude (20 to $60 \mu \mathrm{g}$.) do not produce measurable changes in serum folate levels given orally or even intravenously.

\section{Urinary Excretion of Folate after Oral Doses}

Urine was collected for six hours after oral folate into a bottle containing about $0.5 \mathrm{~g}$. of dry ascorbate. Following oral doses of $0.045 \mu \mathrm{M} / \mathrm{kg}$. body weight a mean of 159 to $266 \mu$ g. appeared in the urine after PteGlu (Tables I and II),

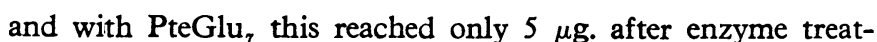
ment. This confirms the poor intestinal absorption of heptaglutamate and good absorption of monoglutamate, of which some $20 \%$ of the oral dose was excreted in the urine.

\section{Effect of Daily Supplement on Red Cell Folate Levels}

The folate content of red cells is a good indication of the folate status of the individual and is closely correlated with the dietary intake of folate (Chanarin et al., 1968). Eighteen healthy members of the hospital and laboratory staff were asked to take a daily folate supplement of $0.227 \mu \mathrm{M}$. Twelve had one tablet containing $100 \mu \mathrm{g}$. $(0.227 \mu \mathrm{M})$ PteGlu daily for five months and six had 17 tablets of yeast (5.1 g.) supplying the equivalent amount of PteGlu $\mathrm{P}_{7}$ daily for three months. Blood for red cell folate estimation was taken before the start of the study and at monthly intervals for eight months in those receiving PteGlu and more frequently in those receiving PteGlu $_{7}$. All the specimens were stored at $-20^{\circ} \quad \mathrm{C}$. and assayed simultaneously. The results (Fig. 2) show that with PteGlu there was a slow rise in red cell folate over two months to reach a plateau some $45 \%$ above baseline levels, but with $\mathrm{PteGlu}_{7}$ the increase was only $16 \%$. On this basis oral heptaglutamate was utilized to one-third of the extent of monoglutamate. In retrospect we would have liked to have more than one initial baseline red cell folate level in the heptaglutamate study, since there were unexplained transient rises in red cell folate in the two weeks after the start of the study.

Following withdrawal of the $100-\mu \mathrm{g}$. folate supplement red cell folate showed a slow decline starting after three months, suggesting reutilization of the augmented folate stores.

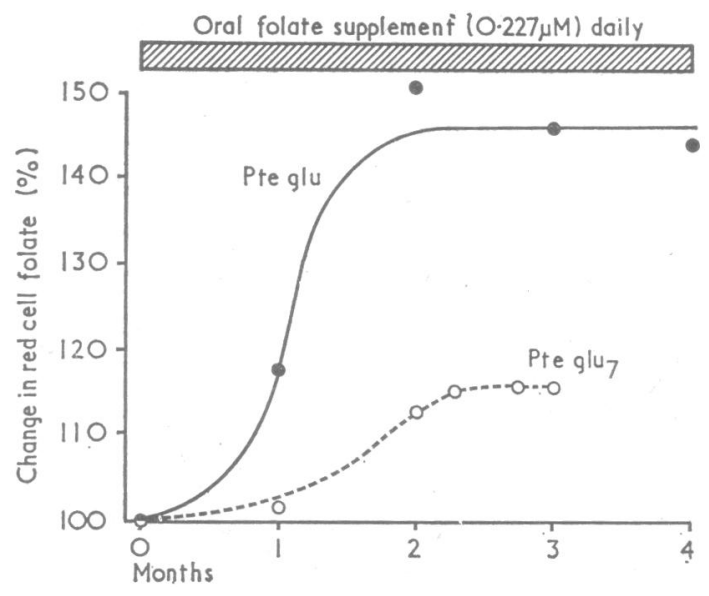

FIG. 2.-Relative change in red cell folate levels in 12 healthy subjects receiving $0.227 \mu \mathrm{M}$ (100 $\mu \mathrm{g}$.) pteroylglutamic acid daily and in six healthy subjects receiving $0.227 \mu \mathrm{M}$ pteroylheptaglutamic acid daily.

\section{Comparison of Haematological Response}

Five patients with megaloblastic anaemia due to folate deficiency were treated with yeast tablets supplying the "free" folate equivalent of 50 to $200 \mu \mathrm{g}$. of folate daily. Two of these patients had idiopathic steatorrhoea, and neither showed any response to 36 yeast tablets (supplying the equivalent of $200 \mu \mathrm{g}$. as heptaglutamate daily). Two other patients were old women with nutritional folate deficiency, and the third a post-gastrectomy patient whose megaloblastic anaemia was due to folate deficiency (? nutritional). One failed to respond to 12 yeast tablets daily, but two others had reticulocyte responses to PteGlu. In these two the marrow remained megaloblastic and was followed by a second reticulocyte response when an equimolar (or smaller) amount of PteGlu was substituted. The second response was associated with a fall in the serum iron and return of a normoblastic marrow. The response in the 76-year-old postgastrectomy patient is shown in Fig. 3. 
These responses confirm relatively poor utilization by man of PteGlu ${ }_{7}$ and better utilization of simpler forms of folate.

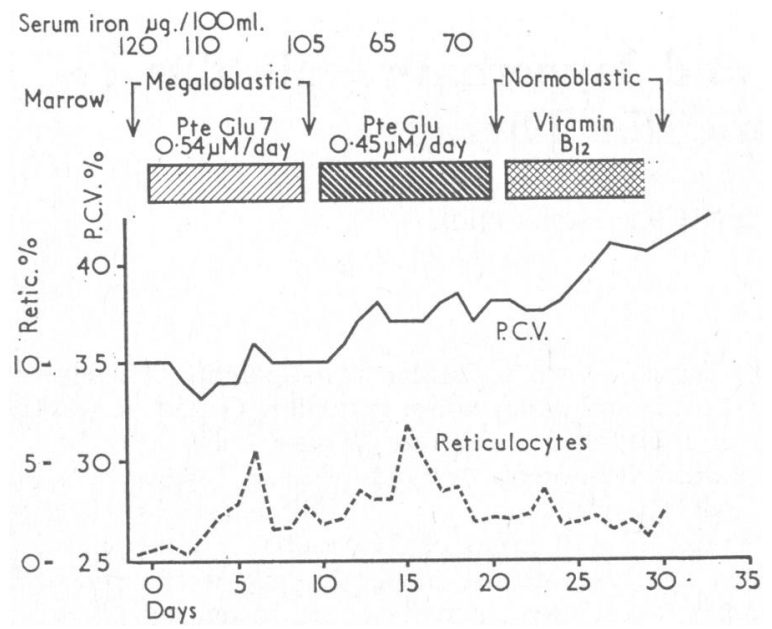

FIG. 3.- Haematological response in patient with megaloblastic anaemia due to folate deficiency first to heptaglutamate then to a slightly smaller dose of monoglutamate, and finally to vitamin $\mathbf{B}_{12}$.

\section{Discussion}

The observations in this study indicate poor absorption and utilization of dietary heptaglutamate as compared with monoglutamate. The free folate content of a large number of daily diets was $160 \mu \mathrm{g}$., and on the basis of $80 \%$ absorption shown with tritium-labelled folate (though in fasting subjects) a maximum absorption of some $128 \mu \mathrm{g}$. can be anticipated. The data on incorporation of folate into red cells suggest that PteGlu is used to about one-third of the extent of PteGlu. On this basis, if absorption is one-third of the $80 \%$ absorbed with PteGlu, some $27 \%$ of PteGlu is $_{7}$ taken up. This would suggest a folate utilization of $128 \mu \mathrm{g}$. as free folate and a further $140 \mu \mathrm{g}$. (27\% of $516 \mu \mathrm{g}$. of $\mathrm{PteGlu}_{7}$ in an average diet) as PteGlu giving a total average folate intake in man of $270 \mu \mathrm{g}$. daily expressed in terms of PteGlu.

Man differs from some other species in his relatively poor utilization of heptaglutamate (M.W. 1216) as compared with monoglutamate (M.W. 441). In the chick heptaglutamate appears to be fully utilized (Jukes, 1955).

Jandl and Lear (1956), studying the uptake of yeast folate, found, as we did, that $25 \%$ of folate in unaltered yeast was absorbed, and this was increased to $60 \%$ when the yeast was pretreated with conjugase enzyme, but that even this was not as well absorbed as an equivalent of pteroylglutamic acid.

Spray (1952) compared the absorption of pteroylglutamic acid $(1 \mathrm{mg}$.) and yeast folate in equivalent amount and noted poor absorption of the yeast folate. Though he did not explore the effect of enzyme on the serum folate level our observations show that this would not have changed the overall pattern significantly. Spray (1952) and Spray and Witts (1952) also showed that with oral yeast only some $2 \mu \mathrm{g}$. of folate appeared in the urine as compared with some $69 \mu \mathrm{g}$. after pteroylglutamic acid. More recent studies have been those of Cooperman and Luhby (1965), who in a single case claimed high plasma levels of unaltered heptaglutamate after oral dosage, and Streiff and Rosenberg (1967), who gave only $10 \mu \mathrm{g}$. of Pte Glu 7 orally-too small a dose to have an effect on plasma levels.

Haematological responses to oral yeast therapy have been well known since the observation of Wills (1931) on the treatment of megaloblastic anaemia in pregnancy in Bombay. She, and most workers, used Marmite, an autolysed yeast which has a relatively higher proportion of free folate. Wintrobe (1939), in a review, concluded that one-third of patients showed some response to oral yeast, given in doses of often up to $45 \mathrm{~g}$. of Marmite daily, supplying about $12 \mu \mathrm{g}$. of folate per g., of which
$2 \mu \mathrm{g}$. might be free folate. Many of the responses could be largely attributed to the free folate content of the autolysed yeast preparation.

Both Welch, Heinle, Nelson, and Nelson (1946) and Bethell, Meyers, Andrews, Swendseid, Bird, and Brown (1947) reported examples of pernicious anaemia patients who failed to respond to polyglutamyl forms of folate and then responded to the equivalent amount of pteroylglutamic acid.

The absorption of some $270 \mu \mathrm{g}$. daily from a normal diet does not represent a vast excess of intake over requirement. This quantity is inadequate to meet the requirements of normal pregnancy-for example, where some additional $100 \mu \mathrm{g}$. of folate daily has to be supplied in order to prevent a progressive decline in red cell folate levels (Hansen and Rybo, 1967; Chanarin et al., 1968).

The suggestion that $50 \mu \mathrm{g}$. of folate represents the normal requirement was put forward by Herbert (1962). We feel that the data in that paper have been misinterpreted. All three subjects in the study who received from 25 to $100 \mu \mathrm{g}$. of folate daily showed a declining serum folate value-that is, all had a lower level at the end of the study than at the beginningindicating that up to $100 \mu \mathrm{g}$. of folate daily was not enough to maintain serum folate levels. That the serum folate level in the only subject on $25 \mu \mathrm{g}$. of folate daily fell to below $5 \mathrm{~m} \mu \mathrm{g} . / \mathrm{ml}$. is hardly relevant, as the levels were falling in all the three subjects, and had the study been continued no doubt the levels would have declined to $5 \mathrm{~m} \mu \mathrm{g}$. or any other level chosen as meaningful. It seems more important that in that widely misquoted study insufficient folate was taken by all three volunteers to sustain their own normal folate values, and the only conclusion that can be drawn is that the requirement was greater than $100 \mu \mathrm{g}$. daily.

Other studies have been concerned wth the absorption of large doses of synthetic diglutamate and triglutamate forms of folate, but these do not throw light on utilization of food folate (Baker et al., 1965).

Attention has also been focused on the amount of folate required to produce an adequate haematological response in folate-deficient megaloblastic anaemia. This amount has varied from 25 to $800 \mu \mathrm{g}$. daily, depending on whether there is any increased folate requirement or not, and most patients respond to $200 \mu \mathrm{g}$. There is, however, no evidence which indicates that the dose producing a haematological response is necessarily the same as the amount of folate required each day to maintain the normal physiological status.

\section{REFERENCES}

Anderson, B., Belcher, E. H., Chanarin, I., and Mollin, D. L. (1960). Brit. 7. Haemat., 6, 439.

Asatoor, A., and Dalgliesh, C. E. (1956). F. chem. Soc., 2291

Baker, H., et al. (1965). Amer. f. clin. Nutr., 17, 88

Bethell, F. H., Meyers, M. C., Andrews, G. A., Swendseid, M. E., Bird, O. D., and Brown, R. A.' (1947). F. Lab. clin. Med., 32, 3.

Binkley, S. B., et al. (1944). Science, 100, 36.

Butterworth, C. E., Santini, R., and Frommeyer, W. B. (1963). F. clin. Invest., 42, 1929.

Chanarin, I., and McLean, A. (1967). Clin. Sci., 32, 57

Chanarin, I., Rothman, D., Perry, J., and Stratfull, D. (1968). Brit. med. f., 2,394

Cooperman, J. M., and Luhby, A. L. (1965). Israel f. med. Sci., 1, 704. Hansen, H., and Rybo, G. (1967). Acta obstet. gynec. scand., 46, Suppl. No. 7, p. 107

Herbert, V. (1962). Arch. intern. Med., 110, 649.

Hoffbrand, A. V.; Newcombe, B. F. A., and Mollin, D. L. (1966), 尹. clin. Path., 19, 17.

Iwai, K., Luttner, P. M., and Toennies, G. (1964). f. biol. chem., 239,

Jandl, J. H., and Lear, A. A. (1956). Ann. intern. Med., 45, 1027.

Jukes, T. H. (1955). Meth. biochem. Anal., 2, 121 .

Pfiffner, J. J., Calkins, D. G., Bloom, E. S., and O’Dell, B. L. (1946). ₹. Amer. chem. Soc., 68, 1392 .

Amer. chem. Soc., 68, 1392. $11,425$.

Spray, G. H. (1952). Clin. Sci., 11, 425.

Streiff, R. R., and Rosenberg, I. H. (1967). f. clin. Invest., 46, 1121.

Welch, A. D., Heinle, R. W., Nelson, E. M., and Nelson, H. V. (1946). F. biol. Chem., 164, 787

Wills, L. (1931). Brit. med. F., 1, 1059

Wintrobe, M. M. (1939). Amer. f. med. Sci., 197, 286. 